\title{
SHAMOON V CHIEF CONSTABLE OF THE RUC - WHAT IT SAYS ABOUT THE CONTEMPORARY LEGAL POSITION OF UNLAWFUL SEX DISCRIMINATION
}

\author{
Julie McCandless, Gender Sexuality and the Family Research \\ Student, Cornell University Law School
}

In February of this year, the House of Lords passed judgment, in favour of the respondent, on the sex discrimination case Shamoon v Chief Constable of the Royal Ulster Constabulary. ${ }^{1}$ In December 1997, the appellant, Chief Inspector Shamoon, lodged an application with the Industrial Tribunal for Northern Ireland, alleging that she had been unlawfully discriminated against on the ground of her sex, contrary to article 3 of the Sex Discrimination (Northern Ireland) Order $1976 .^{2}$ The House of Lords' judgment, almost thirty years since the enactment of the legislation, highlights the still continuing statutory and evidential difficulties in proving an alleged case of direct discrimination, and the importance of understanding and satisfying the basic principles of the Order .

\section{The Facts}

The key facts of the case were as follows. The appellant, at the time of her complaint, had been a serving member of the RUC for twenty-two years, and a Chief Inspector since 1995. She was employed in Urban Traffic, one of three RUC Traffic Branches, and in 1997, Superintendent Laird, the alleged discriminator, ${ }^{3}$ became her immediate superior officer. The RUC operated a Staff Appraisal Scheme and by 1997 it had become established practice throughout the Force for Chief Inspectors to carry out such appraisals for lower ranking officers, even though clause 3.2 of the Scheme provided that Superintendents should perform the task.

In April 1997 a constable made a complaint to Superintendent Laird regarding how Chief Inspector Shamoon had conducted her appraisal. He upheld the complaint. In September 1997 another constable, Constable Currie, made a second complaint about the appellant's appraisals. He was dissatisfied with an analogy the appellant had made about his unwillingness to discuss problems and an unadmittent alcoholic. After a discussion with the Superintendent, who was aware of what the comments referred to, the appellant reluctantly agreed to delete the analogy from her report. The Constable however, took his complaint to the Police Federation, and on 6 October a meeting was held between representatives of the Police Federation and Superintendent Laird to discuss staff appraisals. ${ }^{4}$ During the meeting the

1 [2003] UKHL 11.

2 The Northern Ireland equivalent to the Sex Discrimination Act 1975.

3 The Chief Constable of the RUC was the named respondent by virtue of vicarious responsibility as provided for in article 42(1) of the Order.

4 In his evidence given at the hearing, Superintendent Laird claimed that it was a general meeting, not directly related to the appellant and Constable Currie, and that the latter were merely briefly referred to. The tribunal was highly sceptical about this given the result of the meeting. 
Federation brought clause 3.2 to the Superintendent's attention, whereupon he agreed that he should follow the strict letter of the scheme. Important to this outcome was the fact that it was common knowledge that from December 1997 the policy would be changed, with the result that appraisals would thus forth be carried out formally by Chief Inspectors.

When the appellant was informed about the outcome of the meeting, she immediately expressed her dissatisfaction at what she viewed as Superintendent Laird's failure to stand-up to the Federation on her behalf and resist their demands, pointing out that the male Chief Inspectors in the North and South divisions of Traffic Control were still doing appraisals. The Superintendent responded that he was only concerned with what happened in Urban Traffic Control, and that he felt it important to keep on the right side of the Federation. The appellant told him that she felt discriminated against, that her position had been undermined and that she wished to evoke the grievance procedure. This she did not formally do, but instead lodged the above mentioned complaint.

\section{The Legislation}

To establish a case of direct discrimination based on sex, the following provisions of the Order must be satisfied. Article 3(1) provides:

"A person discriminates against a woman in any circumstances relevant for the purposes of any provision of this Order if -

(a) on the ground of her sex he treats her less favourably than he treats or would treat a man..."

Article 7, entitled "Basis of comparison", provides:

"A comparison of the cases of persons of different sex or marital status under article 3(1) or 5(1) must be such that the relevant circumstances in the one case are the same, or not materially different, in the other."

The relevant provision dealing with discrimination in the employment field is article $8(2)$ :

"It is unlawful for a person, in the case of a woman employed by him at an establishment in Northern Ireland, to discriminate against her -

(a) in the way he affords her access to opportunities for promotion, transfer or training, or to any other benefits, facilities or services, or by refusing or deliberately omitting to afford her access to them, or

(b) by dismissing her, or subjecting her to any other detriment."

The Industrial Tribunal found in favour of Chief Inspector Shamoon. The respondent then appealed to the Court of Appeal, which upheld the appeal on the basis that none of the questions of law had been satisfied. Chief Inspector Shamoon then appealed to the House of Lords who found some, but not all, of the criteria satisfied, thus dismissing her appeal. 


\section{What Must Be Proven?}

In light of the above provisions, two questions must be answered satisfactorily to show unlawful direct discrimination. Firstly, was the appellant subjected to a 'detriment' within the meaning of article 8(2)(b) when Superintendent Laird stopped her from carrying out staff appraisals? Secondly, under articles 3(1)(a) and 7, in the relevant circumstances and on the ground of her sex, had Superintendent Laird treated her less favourably than he treated or would have treated a man in the same or not materially different circumstances?

\section{Detriment}

The tribunal seems to have assumed detriment under article $8(2)$ (b) when Superintendent Laird 'removed' the appellant from her right to continue to do appraisals on constables. ${ }^{5}$ However, the question of article $8(2)$ (b) was not raised at the hearing by way of evidence, cross-examination or submissions by either party, and was in fact not expressly dealt with in the Tribunal's decision.

The Court of Appeal took a particularly narrow definition of detriment under article 8(2)(b), and failed to find it in the appellant's case. Approving the Employment Appeal Tribunal's meaning of the word in Lord Chancellor v Coker and Osamor ${ }^{6}$ they held that it had to be interpreted in accordance with the word 'dismissing' in the same paragraph, thus there had to be some physical or economic consequence. This, said Carswell LCJ, was in accordance with the decision of the Court of Appeal in Barclays Bank plc $\mathrm{v}$ Kapur and others $(\text { No 2 })^{7}$ that an unjustified sense of grievance cannot amount to detriment. He said the appellant was unjustified in her grievance, because she had in fact no 'right' to carry out the appraisals, and suffered no loss of rank or no financial consequence when the position was removed from her.

By the date the appeal came to the House of Lords, the respondent had to concede, given the House of Lords' decision in Chief Constable of the West Yorkshire Police $\mathrm{v}$ Khan, ${ }^{8}$ that the Court of Appeal's decision on this point could not stand. This case affirmed previous cases ${ }^{9}$ - which predated the Court of Appeal's decision, but had not been mentioned in the judgment that gave detriment a wide construction, far beyond financial loss. Lord Hope said that essentially, the appellant had to show that her disadvantage was a detriment within the employment field by virtue of article $8(2)$ (b), by showing that by reason of the act or acts complained of, a reasonable worker would or might take the view that he had thereby been disadvantaged in the circumstances in which he had thereafter to work. ${ }^{10}$ He also drew attention to Lord Hoffmann's point that an industrial/employment tribunal has

5 Para 10, tribunal report.

6 [2001] IRLR 116.

7 [1995] IRLR 87.

8 [2001] UKHL 48; [2001] 1 WLR 1947.

9 Ministry of Defence v Jeremiah [1980] QB 87, 104B; De Souza v Automobile Association [1986] ICR 514, 522G; Barclays Bank plc v Kapur [1989] IRLR 387.

10 Para 34, in accordance with May LJ in De Souza v Automobile Association, ibid. 
jurisdiction to award compensation for injury to feelings, the relief the appellant was actually seeking. This provided a further reason to give detriment a broad definition, beyond its literal context within the other comprehensive employment terms in article $8(2) .{ }^{11}$ The only other limitation, said Lord Hope, was that of materiality - was it a justified sense of grievance or detriment given all the circumstances?

Despite the tribunal not making an express finding on this issue, the House unanimously found material in the evidence from which the appellant was entitled to a finding that she had suffered a detriment within the meaning of article 8(2)(b). It was currently 'endemic' throughout the force for Chief Inspectors to carry out appraisals, and this would become a formal procedure in three months time. In light of this, once it became known that these responsibilities had been taken away from her, the effect was likely to reduce the appellant's standing among her colleagues. A reasonable worker, in the view of the House, would be entitled to feel that she was being demeaned over those whom she had authority, and thus suffering a 'detriment'.

\section{Less Favourable Treatment by Way of Sex}

Our second question focuses upon articles 3(1)(a) and 7. Although asking a single question, article 3(1)(a) has normally been divided by tribunals and courts into two legislatively required parts. Firstly, did the claimant, given the relevant circumstances, receive less favourable treatment compared to how her employer treated or would have treated a man? Secondly, was the reason for this less favourable treatment based on the prohibited grounds of sex? It has been accepted that the legislation calls for a comparison between the claimant and a male comparator. For the purposes of article 3, a choice must be made as to what circumstances are relevant or irrelevant in respect of both the comparison for determining less favourable treatment, and in deducing the reason for it. Article 7 delineates the test for the application of this rule:

"[the comparison] must be such that the relevant circumstances in the one case are the same, or not materially different, in the other."

\section{The Tribunal's Reasoning}

The tribunal proceeded on the basis that the two male Chief Inspectors in the North and South branches were suitable comparators, as their work was not materially different from the appellant's. The appellant's counsel, relying on Lord Nicholls' approach to comparators in the victimization case Chief Constable of the West Yorkshire Police v Khan, ${ }^{12}$ argued that the complaints and representations, which were unique to the appellant, were not relevant circumstances in establishing a comparator for 'less favourable treatment', but were instead only 'reason why' points. The tribunal essentially accepted this approach and were sceptical about the respondent's reasons for removing appraisals from the appellant. Constable Currie's report had been

11 Not just by analogy with the word 'dismissal' in article 8(2)(b), as the Court of Appeal had suggested.

12 See $\mathrm{n} 8$ above. 
amended by the time of the meeting with the Federation, and the Federation had not made any further representations about the appropriateness of Chief Inspectors carrying out appraisals. A majority of the tribunal was thus satisfied that this aspect of the legislation had been satisfied. ${ }^{13}$

\section{The Court of Appeal's Ruling}

The Court of Appeal opinion was in direct contrast to the tribunal. They ruled that the appellant had failed to show less favourable treatment by use of a valid comparator, and consequently that such treatment was based on sex. Applying Chief Constable of the $R U C \mathrm{v} A,{ }^{14}$ which held that those circumstances on which a reasonable person would place some weight in determining how to treat another were to be taken into account, Carswell LCJ ruled that the complaints made against the appellant regarding appraisals, and the subsequent representations made by the Federation, were circumstances which a reasonable person could not ignore in comparing the applicant with the other male Chief Inspectors. The Court of Appeal thus ruled that the claimant had failed to establish a valid comparator, and that subsequently her claim could not be evidenced. They did, however, proceed to discuss the 'reason why' issue, concluding that while the tribunal was entitled to entertain the possibility that such an assumed difference of treatment could be based on sex and look to the employer for an explanation, ${ }^{15}$ they were satisfied by the explanation given by the respondent that the removal of appraisals was because of the complaints and the Federation representations and not the appellant's sex.

\section{The House of Lords' Judgment}

The House of Lords agreed with the Court of Appeal that the tribunal misdirected itself that the male Chief Inspectors were valid comparators. They rejected the appellant's argument regarding comparators because the test propounded in Chief Constable of the West Yorkshire Police v Khan ${ }^{16}$ applied only to victimization and not direct discrimination. They said that while the same principle of comparing 'like with like' applied to both situations, the test for the 'relevant circumstances' is different. Article 6, dealing with victimization, lays down a test naturally falling into two parts. Article 7 however, which provides the test to be applied to direct sex discrimination in article 3(1), is a single test that must be applied to the article as a whole. ${ }^{17}$ Therefore, circumstances that apply to one part cannot be ignored for the other, even if the two issues are considered separately. ${ }^{18}$ Lord Rodger described the relevant circumstances in article 7 as those which the alleged discriminator takes into account, or fails to take into account,

13 Para 3.13 of the tribunal's decision. There was one person in the minority.

4 [2000] NI 261, at 271.

15 See the approach in King v Great Britain China Centre [1992] ICR 516, 528-529; Zafar v Glasgow City Council [1998] IRLR 36, 38-39.

16 See $\mathrm{n} 8$ above.

17 The heading of the article, 'Basis of comparison', is confusing in that it could lead one to believe that it applied only to the comparative 'less favourable treatment' issue, and not the 'reason why' issue.

18 Per Lord Hope, paras 47-49. 
when deciding to treat the woman as he does, compared to how he treats or would treat a man. ${ }^{19}$

On this basis, the House ruled that the complaints made against her, the representations from the Federation and the fact that it was Superintendent Laird who was her superior and not another Superintendent, were relevant circumstances which made the appellant's situation 'materially different' from the male Chief Inspectors. However, they also ruled that for the Court of Appeal to say that the failure to find an actual comparator was detrimental to her claim, was wrong, defeated the point of the legislation and was contrary to the wording 'or would treat' a man. ${ }^{20}$ When an appropriate male comparator cannot be found, the legislation, in accordance with Chief Constable of West Yorkshire v Vento ${ }^{21}$ allows for a hypothetical comparator.

The Lords' opinions on this issue all serve to highlight that the need for a comparator has been one of the most limiting and divisive aspects in sex discrimination cases, and indeed discrimination cases in general. ${ }^{22}$ Choices as to what are the relevant circumstances and characteristics of the comparator are often singly determinative of the outcome of the case. ${ }^{23}$ It was recognised that comparators will generally be hypothetical and, in contrast to the Court of Appeal, little restriction on relevant evidence from which discrimination inferences could be drawn was encouraged where no actual comparator could be found. ${ }^{24}$ The House also highlighted that while actual comparators may not be statutory article 7 comparators, the former may still have an evidential role in drawing inferences. The evidential strength of such would depend on 'material differences', and in the present case were thought to render the male Chief Inspectors of insufficient evidential value. ${ }^{25}$ Indeed, Lord Nicholls said that it may be beneficial for tribunals, if they are to divide the question, to attempt to answer the 'reason why' issue as their initial threshold, rather than get into complicated questions posed by finding a suitable comparator for the 'less favourable treatment' issue which is currently the more usual initial threshold. He emphasised that the issues were often so intertwined, especially in the present case, and that by answering 'why' the appellant had the duty of appraisals taken from her, the issue of 'less favourable treatment' may consequentially be answered. As well as that the question of what factual differences, such as the complaints and representations were in fact 'material differences', could be answered more clearly. ${ }^{26}$

In the third issue we must examine the reason why the appellant had the duty of appraisals taken away from her. It was on this issue that the opaque

19 Per Lord Rodger, paras 134-136.

20 In paragraph 83 Lord Hutton said that he believed the Court of Appeal did not fail to consider a possible hypothetical male comparator, quoting Carswell LCJ at page 11. However this passage does not make the comparison particularly clear.

21 [2001] IRLR 124.

22 See further Sandra Fredman, Women and the Law (Clarence Press, Oxford, 1997).

23 See Advocate General v McDonald [2001] SCI; Pearce v Governing Body of Mayfield School [2001] EWCA Civ 1347, [2002] ICR 198; Case C-249197 Gruber v Silhouette International Schmied GmbH \& Co.KG [1999] ECR 1-4799.

24 Per Lord Rodger, paras 142-143.

25 Per Lord Scott, paras 109-114.

26 Per Lord Nicholls, paras 9-11. 
judgement of the tribunal guaranteed the dismissal of the appeal by the Lords. The Lords rightly recognised the subtlety of sex discrimination, and that in fact people may not even be aware that they're doing it, let alone admit to it, or there be direct evidence of it. Therefore, the finding of unlawful sex discrimination usually depends on what inferences are drawn by the tribunal on hearing the evidence first hand. They urged appellate courts to be aware of this advantage that tribunals have, and of the conditions that tribunals operate in - their judgments will not be that of a High Court judge, so should not be as rigorously analysed. However, they also acknowledged that, in accordance with Meek v City of Birmingham District Council, ${ }^{27}$ a tribunal must state the reasons which led them to reach their conclusions, especially when, as in this case there is both a majority and a minority opinion.

In the light of paragraphs 3.8 and $3.11-13$ of the tribunal's reasoning, the House believed that the tribunal may have drawn the following inference Superintendent Laird may not have given in so easily to the Federation's demands, and acted so hastily, if Chief Inspector Shamoon had been a man. Thus, the appellant received less favourable treatment because of her sex. The tribunal pointed out that the only result of the meeting (according to Superintendent Laird's evidence this was not directly about the appellant or Constable Currie's report, which he maintained had already been amended to omit the offending analogy $)^{28}$ was that Chief Inspector Shamoon had the duty of appraisals removed from her, despite the forthcoming procedural change. Superintendent Laird must have been aware of the fact that this was not the case for the other Traffic Branch male chief inspectors, and that the appellant had been singled out. The tribunal went on to suggest several other options which Superintendent Laird could have taken. He could have asked if the Federation were proposing to take the issue of appraisals up with the Force generally; whether, given the impending December rule change it was really necessary to follow the strict letter of the scheme; sought further guidance from the Federation; checked what other regions were doing; or discussed it at the monthly meeting of senior officers.

However, the House concluded that the above could only be an assumption as the tribunal had failed to state such or produce conclusive factual evidence of it. They concluded that the tribunal, proceeding on the incorrect assumption that the male chief inspectors in the North and South Branches were suitable comparators, established only that the appellant had been treated differently from the other male chief inspectors, not the actual reason why she had been treated differently. Lord Nicholls entertained the possibility that a well-reasoned argument by the tribunal might have succeeded, and was the only member of the House to consider the possibility of a re-hearing on the basis of insufficiency of reasons. However, as the other Lords all believed there to be insufficient evidence on which a properly directed tribunal could have upheld the claimant's application, he declined to

27 [1987] IRLR 250, at 251.

28 The tribunal was noticeably sceptical about Superintendent Laird's evidence here. They concluded that the appellant and Constable Currie's report were the reasons for the meeting and had to be discussed directly, and found that in fact Constable Currie's report was not amended until after the meeting. 


\section{Northern Ireland Legal Quarterly [Vol. 54, No. 3]}

dissent on this point. ${ }^{29}$ Such evidence, when the case relies on a hypothetical comparator, could be findings on how Superintendent Laird treated male officers in other, not wholly dissimilar circumstances. ${ }^{30}$ Lord Scott noted that other supporting evidence could be discriminatory comments from the accused, unconvincing denials of discriminatory intent or assertions of other reasons for the alleged discriminatory decision. ${ }^{31}$ In the absence of any such facts, the House dismissed the appeal and rejected the possibility of a rehearing.

\section{Comment}

Sex discrimination is a particularly subtle form of discrimination. The deep permeation of gender differentiation in society and, despite contemporary denials of it by both men and women, female subordination and patriarchy, continue to blight modern lifestyles. By no means should 'The Law' be seen in isolation as the key to changing such values or stopping wrongful sex discrimination - the fact that the Order is still being frequently used after almost thirty years is fact enough alone to establish that much. However, law does have an important practical and symbolic role to play, and the judiciary, as the interpreter of our legislation, holds the task of setting society's legal standards and consequentially some ethical standard of what is acceptable.

Given the importance of vanquishing gender inequality, and the often-elusive nature of evidence demonstrating unlawful sex discrimination, the courts should take great care when deciding such cases to ensure that discrimination is recognised and taken seriously as legally wrongful conduct.

In the present case, several things can be criticised from a gender-orientated perspective. Firstly, the tribunal, whilst ruling in Chief Inspector Shamoon's favour, actually ensured the final dismissal of her case by their misunderstanding of what the law required. Lack of resources, time and training may more than anything account for such errors, but this does not help true victims establish already hard-to-prove cases. The Court of Appeal's perspective on what could be termed a 'detriment' within the employment field was particularly narrow. The male judges sitting in that court failed to appreciate that there is more than financial loss affecting one's standing in a job. They also displayed a poor understanding of the law in relation to comparators, which were already established by the case law and easily allowed for by the wording of the Order.

Finally, the House of Lords, by comprehensively explaining the law and reasoning the case, went some way to recognising the possibility of unlawful sex discrimination in the circumstances of the case. However it was regrettable that having found the tribunal misdirecting itself in law, on a very subtle and difficult legal question, the House did not give the appellant a chance to put the right questions to the tribunal at a rehearing.

A feminist critique of anti-sex discrimination laws would require a whole new article which space does not here provide for. However, maybe a fitting

29 At paras 14-15.

30 Per Lord Rodger at paras 140-143, 147.

31 At para 116. 
conclusion could be this. This comment on the Shamoon case has hopefully emphasised what a difficult area of law this is, and that the Order is less about preventing a person from being discriminated against than dealing afterwards with proven cases of inequality. It hopefully highlights the need for law and broader social policies to be more positive in nature, to help ensure gender equality, rather than merely dealing with the inequalities. 